\title{
Rhizobium indigoferae sp. nov. and Sinorhizobium kummerowiae sp. nov., respectively isolated from Indigofera spp. and Kummerowia stipulacea
}

\footnotetext{
${ }^{1}$ College of Biological Sciences, China Agricultural University, Beijing 100094, People's Republic of China

${ }^{2}$ Northwest Science and Technology University of Agriculture and Forestry, Yangling, Shaanxi 712100, People's Republic of China

${ }^{3}$ Departamento de Microbiología, Escuela Nacional de Ciencias Biológicas, Instituto Politécnico Nacional, Prol. de Carpio y Plan de Ayala s/n, 11340, México DF, Mexico
}

\author{
Ge Hong Wei, ${ }^{1,2}$ En Tao Wang, ${ }^{3}$ Zhi Yuan Tan, ${ }^{1}$ Ming E Zhu ${ }^{2}$ \\ and Wen Xin Chen ${ }^{1}$
}

\begin{abstract}
Author for correspondence: Wen Xin Chen. Tel: +86 10 62891854. Fax: +86 1062891055. e-mail: wenxin_chen@263.net
\end{abstract}

\begin{abstract}
Forty-eight rhizobial isolates from root nodules of Indigofera and Kummerowia, two genera of annual or perennial wild legumes growing in the Loess Plateau in north-western China, were characterized by a polyphasic approach. Two main groups, cluster 1 and cluster 2, were defined based upon the results of numerical taxonomy, SDS-PAGE of whole-cell proteins and DNA relatedness. All the isolates within cluster 1 were isolated from Indigofera and they were identified as Rhizobium strains by 165 rRNA gene analysis. DNA relatedness of $29.5-48.9 \%$ was obtained among the cluster 1 isolates and the reference strains for defined Rhizobium species. Cluster $\mathbf{2}$ consisted of isolates from Kummerowia stipulacea and was identified as belonging to Sinorhizobium by 165 rRNA gene analyses. DNA relatedness varied from $5 \cdot 2$ to $41.7 \%$ among the isolates of cluster 2 and reference strains for Sinorhizobium species. Considering the existence of distinctive features among these two groups and related species within the genera Rhizobium and Sinorhizobium, we propose two novel species, Rhizobium indigoferae sp. nov. for cluster 1, with isolate CCBAU $71714^{\top}$ ( = AS 1.3046') as the type strain, and Sinorhizobium kummerowiae sp. nov. for cluster 2, with isolate CCBAU $71042^{\top}$ $\left(=\right.$ AS $\left.1.3045^{\top}\right)$ as the type strain.
\end{abstract}

Keywords: Rhizobium indigoferae, Sinorhizobium kummerowiae, diversity, phylogeny

\section{INTRODUCTION}

Rhizobia are useful bacterial resources because of their symbiotic nitrogen-fixing ability. They form nodules on roots, and occasionally on stems, of many leguminous plants and reduce $\mathrm{N}_{2}$ to ammonia, which can be used by the host plants. In the last two decades, the classification of rhizobia has developed rapidly, mostly by the application of polyphasic taxonomy and by the

Published online ahead of print on 12 July 2002 as DOI 10.1099/ ijs.0.02030-0.

Full details of the $\mathrm{G}+\mathrm{C}$ contents and DNA-DNA relatedness of the individual novel isolates are available as supplementary material in IJSEM Online (http://ijs.sgmjournals.org/)

The GenBank/EMBL/DDBJ accession numbers for the 16S rRNA gene sequences of strains CCBAU $71042^{\top}$ and CCBAU $71714^{\top}$ are AF364068 and AF364067. continual investigation of rhizobial resources. At the time of writing, 31species have been described within six genera: Allorhizobium (de Lajudie et al., 1998b), Azorhizobium (Dreyfus et al., 1988), Bradyrhizobium (Jordan, 1984; Kuykendall et al., 1992; Xu et al., 1995), Mesorhizobium (Jarvis et al., 1982, 1997; Chen et al., 1991, 1997; Nour et al., 1994, 1995; de Lajudie et al., 1998b; Wang et al., 1999), Rhizobium (Amarger et al., 1997; van Berkum et al., 1998; Chen et al., 1997; Jordan, 1984; Lindström, 1989; Martínez-Romero et al., 1991; Segovia et al., 1993; Wang et al., 1998) and Sinorhizobium (Chen et al., 1988; de Lajudie et al., 1994; Rome et al., 1996). Azorhizobium and Bradyrhizobium are phylogenetically divergent from the other rhizobia. The remaining genera, Allorhizobium, Mesorhizobium, Rhizobium and Sinorhizobium, are closely related to each other and they are intermingled with plant-pathogenic bacteria belonging to the genus 
Agrobacterium and non-symbiotic bacteria within the genus Ensifer (Casida, 1982). A novel group of rootnodule bacteria was recently identified as belonging to Methylobacterium (Sy et al., 2001). Although most of the defined root-nodule bacteria are members of the $\alpha$ subclass of the Proteobacteria, novel taxa of rootnodule bacteria, Ralstonia taiwanensis (Chen et al., 2001) and Burkholderia sp. (Moulin et al., 2001), have been reported, both being members of the $\beta$-Proteobacteria.

Legumes in the genera Indigofera and Kummerowia are annual or perennial wild plants. Most of them are drought-tolerant and they are held in high esteem as foliage, green manure crops or in preventing soil erosion (Allen \& Allen, 1981). Kummerowia species are used as herbal medicine in China for treating diarrhoea and fever. These plants form root nodules but their microsymbionts have not been characterized systematically. The north-western Loess Plateau region of China, including the provinces of Shaanxi, Gansu and the Autonomous Region of Ningxia, is located in a temperate zone with a semi-arid climate and soils poor in organic matter. During the summer of 1992, we obtained some rhizobial isolates from different plants and different geographical areas in a survey of rhizobial resources in these regions. Previously, we have characterized isolates from Amorpha fruticosa, Glycyrrhiza, Gueldenstaedtia and other genera according to their geographical or host origin (Wang et al., 1999; Tan et al., 1999). Considering the potential value of Indigofera and Kummerowia in agriculture and reforestation and the unknown taxonomic position of the rhizobia associated with them, we decided to characterize isolates from Indigofera and Kummerowia plants in these regions with a polyphasic approach. The aims of the research were to check the diversity and to classify the isolates by both phenotypic and genetic methods.

\section{METHODS}

Isolates and strains. The isolates and reference strains used are listed in Table 1. The 21 isolates from Indigofera spp. and 27 isolates from Kummerowia stipulacea were fast-growing rhizobia that formed single colonies with diameters of 2-3 mm within 3 days on YMA. Rhizobia were isolated from fresh nodules collected from plants growing in the field by the standard method on YMA medium (Vincent, 1970). Single colonies were picked and checked for purity by repeated streaking and by microscopic examination. Nodulation with the original host plant of each isolate was checked in glass tubes, half-filled with vermiculite, as described by Vincent (1970). The temperature in the greenhouse was kept at $23{ }^{\circ} \mathrm{C}$ during the day and $12{ }^{\circ} \mathrm{C}$ during the night, with illumination of 10000-20000 lux for $14 \mathrm{~h} \mathrm{day}^{-1}$.

Phenotypic characterization and numerical taxonomy. A total of 136 phenotypic features, covering utilization of sole carbon and nitrogen sources, resistance to antibiotics, tolerance of dyes and chemicals, tolerance of different concentrations of $\mathrm{NaCl}$, temperature and $\mathrm{pH}$ ranges for growth and some physiological and biochemical reactions were examined as described previously (Gao et al., 1994) in order to characterize the isolates and strains. The simple matching coefficient $S_{\mathrm{sm}}$ and UPGMA (Sneath \& Sokal, 1973) were used for clustering analysis of phenotypic features. The mean similarity for each isolate within a cluster was estimated to present the phenotypic variation in the cluster, as described previously, and the isolate with the highest mean similarity was chosen as the central isolate or representative for the cluster (Sneath \& Sokal, 1973). Generation time of the isolates was determined spectrophotometrically (Yelton et al., 1983) in YM broth (Vincent, 1970).

SDS-PAGE of whole-cell proteins. Methods described previously (Tan et al., 1997) were used for soluble protein extraction, SDS-PAGE and scanning of the protein patterns using an Extra-Scanner densitometer (LKB). Jaccard's coefficient $\left(S_{\mathrm{j}}\right)$ and UPGMA (Sneath \& Sokal, 1973) were used for cluster analysis.

PCR-based RFLP of 16S rRNA genes. Procedures described previously (Wang et al., 1998) were used for PCR amplification of complete 16S rRNA genes with the universal forward primer P1 and the universal reverse primer P6 (Tan et al., 1997), for digestion of the PCR products with restriction endonucleases $M s p \mathrm{I}, H i n f \mathrm{I}, H a e \mathrm{I}$ and $R s a \mathrm{I}$ and for separation of the digested fragments in $3.0 \%$ agarose gels. Primer P1 (5'-CGggatccAGAGTTTGATCCTGGTCAGAACGCT-3') corresponds to positions 8-37 and primer P6 (5'-CGggatccTACGGCTACCTTGTTACGACTTCACCCC-3') corresponds to positions 1479-1506 in the Escherichia coli 16S rDNA (Willems \& Collins, 1993; Yanagi \& Yamasato, 1993). Lower-case letters indicate the BamHI restriction site.

Amplification, cloning and sequencing of $16 \mathrm{~S}$ rDNA. This study was performed only for representative isolates of the novel clusters. Full-length 16S rRNA genes (1500 bp) were amplified from isolates by PCR in a $100 \mu \mathrm{l}$ reaction mixture using primers $\mathrm{P} 1$ and P6. Amplified 16S rDNA was purified from $0.8 \%$ low-melting-point agarose gel by the method of Wieslander (1979). Purified rDNA and plasmid vector pUC18 were restricted with BamHI and ligated at $14{ }^{\circ} \mathrm{C}$ for $16 \mathrm{~h}$. Ligated plasmids were transformed into E. coli $\mathrm{DH} 5 \alpha$ and transformants were selected using the blue/white screening procedure (Sambrook et al., 1989). Plasmids containing $16 \mathrm{~S}$ rDNA were extracted and purified according to the methods of Tiesman \& Rizzino (1991). Purified plasmids were sequenced using an ABI377 automatic sequencer (Applied Biosystems). Two independent clones of PCR-amplified 16S rRNA genes from each isolate were sequenced.

Sequence analysis and reconstruction of the phylogenetic tree. The 16S rRNA gene sequences obtained and those of related bacteria obtained from GenBank were aligned using the PILEUP program in the Wisconsin package (Genetics Computer Group, 1995). Sequence similarities and a phylogenetic tree were generated and bootstrapped with 1000 subsamples using CLUSTAL w version 1.7 (Thompson et al., 1994). The tree was visualized by using the program TreeView (Page, 1996).

Estimation of DNA G + C content and DNA-DNA relatedness. DNAs were extracted and purified by the method of Marmur (1961). DNA base composition was determined using the thermal melting protocol (De Ley, 1970) and using E. coli K12 as standard. Levels of DNA relatedness were determined by the initial renaturation rate method (De Ley et al., 1970).

Cross-nodulation tests. Standard methods were used (Vin- 
Table 1. Isolates and reference strains used in this research

Culture collections/strain sources: CCBAU, Culture Collection of Beijing Agricultural University, Beijing, China; CFN, Centro de Investigación sobre Fijación de Nitrógeno; CIAT, Centro Internacional de Agricultura Tropical, Cali, Colombia; HAMBI, Culture Collection of the Department of Microbiology, University of Helsinki, Helsinki, Finland; LMG, Bacteria Collection of the Laboratorium voor Microbiologie, University of Ghent, Ghent, Belgium; NZP, Culture Collection of the Department for Scientific and Industrial Research, Biochemistry Division, Palmerston North, New Zealand; USDA, Rhizobium Culture Collection, Beltsville Agricultural Research Center, USDA, Beltsville, MD, USA.

\begin{tabular}{|c|c|c|c|}
\hline Strain/isolate & Host plant & Geographical origin & Year of isolation or reference \\
\hline \multicolumn{4}{|l|}{ Cluster 1 (Rhizobium indigoferae sp. nov.) } \\
\hline CCBAU $71042^{\mathrm{T}}$, CCBAU 71364, CCBAU 71260 & Indigofera amblyantha & Shaanxi, China & 1996 \\
\hline CCBAU 71385, CCBAU 71845 & I. amblyantha & Gansu, China & 1996 \\
\hline CCBAU 71849 & Indigofera carlesii & Shaanxi, China & 1996 \\
\hline CCBAU 71064, CCBAU 71860 & I. carlesii & Gansu, China & 1996 \\
\hline CCBAU 71864, CCBAU 71863, CCBAU 71843 & Indigofera potaninii & Shaanxi, China & 1996 \\
\hline CCBAU 71841, CCBAU 71846, CCBAU 71862, CCBAU 71861 & I. amblyantha & Shaanxi, China & 1997 \\
\hline CCBAU 71710, CCBAU 71718 & I. amblyantha & Ningxia, China & 1997 \\
\hline CCBAU 71848 & I. potaninii & Shaanxi, China & 1997 \\
\hline CCBAU 71865, CCBAU 71840 & I. carlesii & Gansu, China & 1997 \\
\hline \multicolumn{4}{|l|}{ Cluster 2 (Sinorhizobium kummerowiae sp. nov.) } \\
\hline $\begin{array}{l}\text { CCBAU 71713, CCBAU 711, CCBAU 71327, CCBAU 71714 } \\
\text { CCBAU } 71715\end{array}$ & Kummerowia stipulacea & Shaanxi, China & 1996 \\
\hline $\begin{array}{l}\text { CCBAU } 71463, \text { CCBAU } 71481, \text { CCBAU } 71726, \text { CCBAU } 71723, \\
\text { CCBAU } 71725, \text { CCBAU } 71741, \text { CCBAU } 71735, \text { CCBAU } 71321, \\
\text { CCBAU } 71390, \text { CCBAU } 71381, \text { CCBAU } 71738, \text { CCBAU } 71734\end{array}$ & K. stipulacea & Shaanxi, China & 1997 \\
\hline CCBAU 71480, CCBAU 71391, CCBAU 71400, CCBAU 71727 & K. stipulacea & Gansu, China & 1996 \\
\hline CCBAU 71743, CCBAU 71747, CCBAU 71401 & K. stipulacea & Ningxia, China & 1997 \\
\hline \multicolumn{4}{|l|}{ Other rhizobial isolates } \\
\hline CCBAU 71150 , CCBAU 71712 & K. stipulacea & Shaanxi, China & 1996 \\
\hline CCBAU 71269 & K. stipulacea & Gansu, China & 1996 \\
\hline CCBAU 71369 & I. amblyantha & Shaanxi, China & 1996 \\
\hline \multicolumn{4}{|l|}{ Reference strains } \\
\hline Sinorhizobium meliloti USDA $1002^{\mathrm{T}}, 102 \mathrm{~F} 28$ & Medicago sativa & & Jordan (1984) \\
\hline Sinorhizobium medicae USDA $1037^{\mathrm{T}}$ & Medicago truncatula & France & Rome et al. (1996) \\
\hline Sinorhizobium fredii USDA $205^{\mathrm{T}}$, USDA 194 & Glycine soja & Henan, China & Scholla \& Elkan (1984) \\
\hline Sinorhizobium xinjiangense CCBAU $110^{\mathrm{T}}$, CCBAU 108 & G. soja & Xinjiang, China & Chen et al. (1988) \\
\hline Sinorhizobium terangae LMG $7834^{\mathrm{T}}$ & Acacia laeta & Senegal & de Lajudie et al. (1994) \\
\hline Sinorhizobium terangae LMG 6463 & Sesbania rostrata & Senegal & de Lajudie et al. (1994) \\
\hline Sinorhizobium saheli LMG $7837^{\mathrm{T}}$ & Sesbania pachycarpa & Senegal & de Lajudie et al. (1994) \\
\hline Mesorhizobium tianshanense A-IBS ${ }^{\mathrm{T}}, 6$ & Glycyrrhiza uralensis & Xinjiang, China & Chen et al. (1995) \\
\hline Mesorhizobium loti NZP $2213^{\mathrm{T}}$ & Lotus corniculatus & New Zealand & Jarvis et al. (1997) \\
\hline Mesorhizobium loti NZP 2227 & Lotus sp. & New Zealand & Jarvis et al. (1997) \\
\hline Mesorhizobium huakuii CCBAU $2609^{\mathrm{T}}$ & Astragalus sinicus & Nanjing, China & Chen et al. (1991) \\
\hline Mesorhizobium huakuii $\mathrm{A} 106$ & A. sinicus & Hubei, China & Chen et al. (1991) \\
\hline Mesorhizobium ciceri USDA $3383^{\mathrm{T}}$ & Cicer arietinum & Spain & Nour et al. (1994) \\
\hline Rhizobium leguminosarum bv. viceae USDA $2370^{\mathrm{T}}$ & & USA & Jordan (1984) \\
\hline Rhizobium leguminosarum bv. phaseoli $127 \mathrm{~K} 17$ & & USA & Jordan $(1984)$ \\
\hline Rhizobium tropici (type B) CIAT $899^{\mathrm{T}}$ & Phaseolus vulgaris & Colombia & Martínez-Romero et al. (1991) \\
\hline Rhizobium tropici (type B) BR853 & Leucaena leucocephala & Brazil & Martínez-Romero et al. (1991) \\
\hline Rhizobium tropici (type A) CFN 299 & P. vulgaris & Brazil & Martínez-Romero et al. (1991) \\
\hline Rhizobium etli CFN $42^{\mathrm{T}}$ & P. vulgaris & Mexico & Segovia et al. (1993) \\
\hline Rhizobium hainanense $\mathrm{I}_{6} 6^{\mathrm{T}}, \mathrm{H} 14$ & Desmodium sinuatum & Hainan, China & Chen et al. (1996) \\
\hline Rhizobium gallicum USDA $2918^{\mathrm{T}}$ & P. vulgaris & France & Amarger et al. (1997) \\
\hline Rhizobium gallicum FL27 & P. vulgaris & France & Amarger et al. (1997) \\
\hline Rhizobium mongolense USDA $1844^{\mathrm{T}}$ & Medicago ruthenica & Inner Mongolia, China & van Berkum et al. (1998) \\
\hline Rhizobium galegae HAMBI $540^{\mathrm{T}}$ & Galega orientalis & Finland & Lindström et al. (1989) \\
\hline Rhizobium galegae HAMBI 1185 & Galega sp. & UK & Lindström et al. (1989) \\
\hline Rhizobium huautlense $\mathrm{S}_{0} 2^{\mathrm{T}}$ & Sesbania herbacea & Mexico & Wang et al. (1999) \\
\hline Rhizobium giardinii USDA $2914^{\mathrm{T}}$ & P. vulgaris & France & Amarger et al. (1997) \\
\hline Bradyrhizobium elkanii USDA $76^{\mathrm{T}}$ & Glycine max & USA & Kuykendall et al. (1992) \\
\hline Bradyrhizobium japonicum USDA $6^{\mathrm{T}}$ & G. $\max$ & Japan & Jordan (1982) \\
\hline
\end{tabular}

cent, 1970). Plants were grown in pots filled with vermiculite moistened with $\mathrm{N}$-free plant nutrient solution (Vincent, 1970). Nodulation and nitrogen fixation were observed after 1 month. Nodulation by representatives of the novel groups was tested on selected recommended legumes (Graham et al., 1991), including Astragalus sinicus, Medicago sativa, Galega orientalis, Lotus corniculatus, Vigna sinensis, Glycine max, Trifolium repens, Phaseolus vulgaris and Caragana korshinskii.

\section{RESULTS}

\section{Phenotypic characterization and numerical taxonomy}

In the phenotypic characterization, none of the strains or isolates tested used adipate, dextrin, inulin, starch, sorbitol, syringic acid, D-arginine, L-methionine or Lthreonine as a sole carbon source. All strains were sensitive to 50-300 $\mu \mathrm{g}$ kanamycin $\mathrm{ml}^{-1}$ and 100-300 $\mu \mathrm{g}$ 


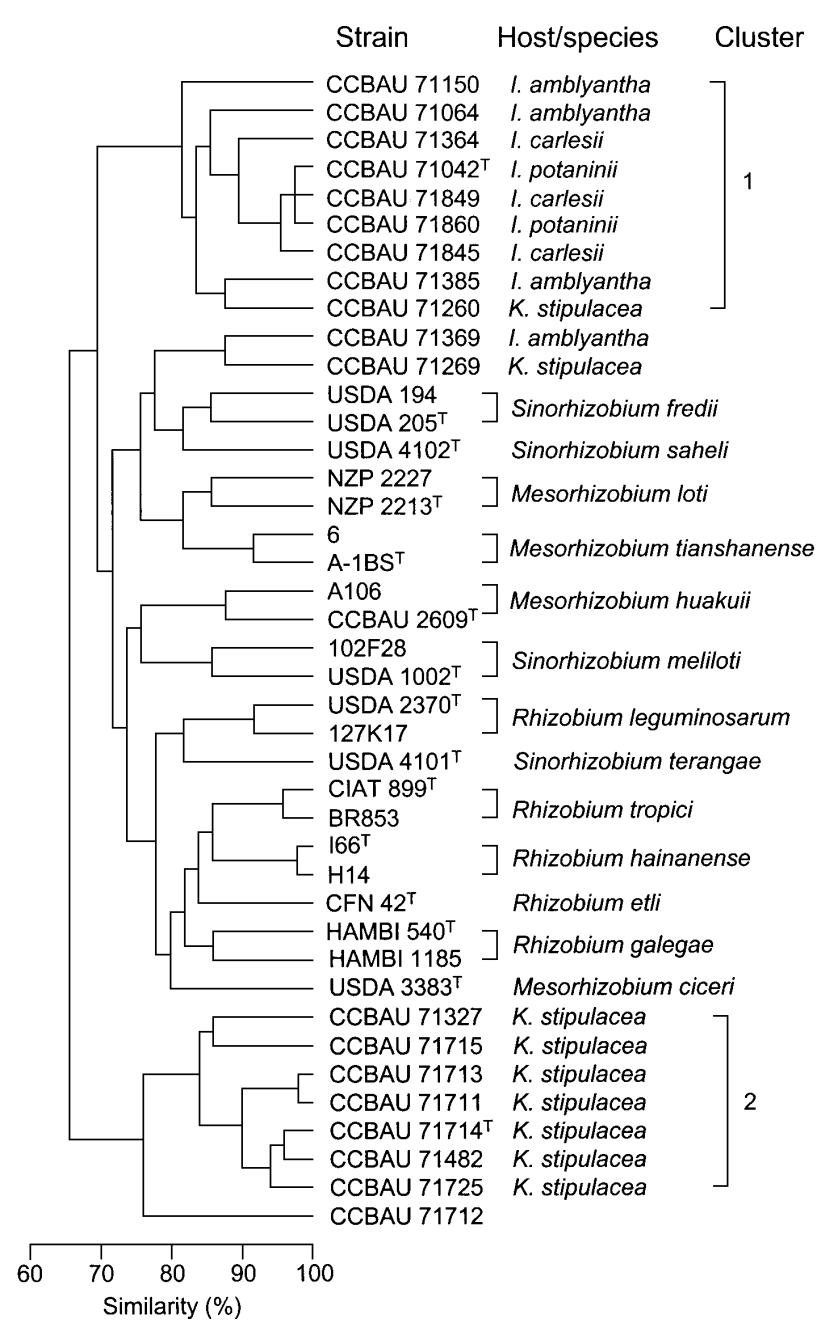

Fig. 1. Phenogram of numerical taxonomy showing the grouping results of the tested strains and isolates. Coefficient $S_{\mathrm{sm}}$ and UPGMA (Sneath \& Sokal, 1973) were used for the clustering analysis of 102 variable features. Clusters were defined at the similarity level of $85 \%$.

neomycin $\mathrm{ml}^{-1}$. No strain could grow in medium supplemented with gentian violet $(0 \cdot 1 \%)$, methylene blue $(0.1 \%)$ or 4.0 or $5.0 \% \mathrm{NaCl}$. No strain grew at $\mathrm{pH} 4.0$ or at 4 or $40{ }^{\circ} \mathrm{C}$. No 3-ketolactose was produced. All strains were resistant to the following antibiotics $\left(\mu \mathrm{g} \mathrm{ml}^{-1}\right)$ : ampicillin (5), bacitracin (5-300), chloramphenicol (5), erythromycin (5 and 50), neomycin (5), polymyxin (5) and streptomycin (5). All strains grew in medium supplied with bismark brown $(0 \cdot 1 \%)$, congo red $(0 \cdot 1 \%)$, erythrosin $(0.1 \%)$, neutral red $(0.1 \%)$, sodium deoxycholate $(0.1 \%)$, sodium nitrite $(0.1 \%)$ or $\mathrm{NaCl}(1.0$ and $2.0 \%)$ and at $\mathrm{pH} 9.0$ and $10 \cdot 0$.

A total of 102 variable features were used for numerical taxonomy. Based on the results of cluster analysis, the isolates formed two clusters while the reference strains were grouped according to species (Fig. 1). Eight of the nine isolates from Indigofera spp. formed cluster 1 and eight of the ten isolates from $K$. stipulacea were grouped into cluster 2 (Fig. 1). The other isolates were single branches. The distinctive phenotype features for cluster 1 and 2 are presented in Table 2. Some important aspects of the two clusters are described below.

Cluster 1 consisted of eight fast-growing isolates from three host species within the genus Indigofera (Indigofera amblyantha, Indigofera carlesii and Indigofera potaninii). The mean similarity for the isolates ranged from $83 \%$ in the case of CCBAU 71260 to $97 \%$ in the case of CCBAU $71042^{\mathrm{T}}$; the latter isolate was chosen as the central isolate for the cluster. Colonies were 2-3 mm in diameter after 2 days on YMA at $28^{\circ} \mathrm{C}$. All the isolates in this cluster produced acid in YMA.

Cluster 2 contained seven isolates from K. stipulacea. The mean similarities ranged from 82 to $96 \%$. Isolate CCBAU $71714^{\mathrm{T}}$ was the central isolate. They were fast-growing, acid-producing bacteria with generation times of $2 \cdot 0-3 \cdot 0 \mathrm{~h}$ in PY broth. No growth was observed in Luria-Bertani broth for these isolates.

\section{SDS-PAGE of whole-cell proteins}

In order to increase the number of strains in clusters 1 and 2 and to investigate the genetic relationships among the isolates and defined species, we performed SDS-PAGE analysis of whole-cell proteins. The grouping results from the protein patterns (Fig. 2) were generally correlated with those from the numerical taxonomy (Fig. 1). The similarities of the protein patterns ranged from 88 to $96.5 \%$ in cluster 1 and 82 to $97 \%$ in cluster 2 . The similarities between different clusters or the type strains for defined species were lower than $79 \%$. The number of isolates was increased to 20 in cluster 1 (from Indigofera spp.) and to 25 in cluster 2 (from K. stipulacea).

\section{PCR-RFLP of 16S rRNA genes}

Based on the grouping results in numerical taxonomy, isolates CCBAU 71042 ${ }^{\mathrm{T}}$, CCBAU 71385 and CCBAU 71064, representing cluster 1, isolates CCBAU $71714^{\mathrm{T}}$, CCBAU 71327 and CCBAU 71713, representing cluster 2, and reference strains for defined species were chosen for PCR-RFLP of 16S rRNA genes. The representative isolates of clusters 1 and 2 gave highly similar patterns, but one or two bands were different within each cluster. Differences were observed between the patterns of isolates from the two clusters and the defined species (not shown). In a cluster analysis of the RFLP patterns, cluster 1 grouped with Rhizobium species and cluster 2 fell in the genus Sinorhizobium (not shown).

\section{Sequencing and phylogeny of 16S rRNA genes}

16S rRNA gene sequences were obtained from isolate CCBAU $71042^{\mathrm{T}}$, representing cluster 1 , and isolate CCBAU $71714^{\mathrm{T}}$, representing cluster 2. Sequences 
Table 2. Distinctive features of the novel clusters and related species defined in numerical taxonomy

Phenons are identified as: $1, R$. etli $(n=2) ; 2$, R. leguminosarum $(n=2) ; 3$, R. tropici $(n=2) ; 4, R$. galegae $(n=2) ; 5, R$. hainanense $(n=2) ; 6, S$. fredii $(n=2) ; 7, S$. meliloti $(n=2) ; 8$, S. terangae $(n=1) ; 9, S$. saheli $(n=1) ; 10$, cluster $1(n=8) ; 11$, cluster $2(n=7)$. Numbers given in the table are percentages of strains testing positive; + , all strains positive; - , all strains negative.

\begin{tabular}{|c|c|c|c|c|c|c|c|c|c|c|c|}
\hline Feature & 1 & 2 & 3 & 4 & 5 & 6 & 7 & 8 & 9 & 10 & 11 \\
\hline \multicolumn{12}{|l|}{ Utilization as sole carbon source: } \\
\hline D-Amygdalin & - & + & - & 50 & - & - & - & - & - & 13 & - \\
\hline D-Arabinose & + & + & + & + & + & + & + & + & - & - & - \\
\hline $\mathrm{D}(+)$-Arabitol & + & - & 50 & - & + & - & + & - & - & 75 & 70 \\
\hline Calcium malonate & - & + & - & + & - & - & - & - & + & - & - \\
\hline Dulcitol & - & + & - & + & + & - & - & + & - & + & + \\
\hline meso-Erythritol & - & - & + & 50 & + & - & + & + & - & 25 & 86 \\
\hline $\mathrm{D}(+)$-Galactose & + & 50 & 50 & + & + & + & + & + & - & + & 29 \\
\hline Lactose & - & + & 50 & + & - & 50 & + & - & - & 88 & - \\
\hline D-Mannose & + & + & + & + & + & + & + & + & - & + & - \\
\hline Sodium citrate & + & + & + & + & + & + & 50 & + & + & + & - \\
\hline Salicin & + & + & - & + & - & - & - & + & - & + & 70 \\
\hline D-Ribose & + & + & + & - & + & - & + & + & - & 25 & - \\
\hline Sodium D-gluconate & + & - & - & 50 & + & - & 50 & - & - & 75 & - \\
\hline D-Sorbitol & + & + & + & + & + & 50 & + & + & + & 75 & - \\
\hline Sucrose & + & - & - & + & + & 50 & - & + & - & + & 30 \\
\hline Tartrate & + & 50 & 50 & 50 & - & + & 50 & - & + & - & - \\
\hline Trehalose & + & + & + & + & + & + & + & + & + & 88 & - \\
\hline Xylose & + & + & + & - & + & 50 & + & - & + & + & 14 \\
\hline DL-Asparagine & + & + & + & 50 & + & + & + & + & + & + & + \\
\hline Glycine & + & - & + & 50 & + & 50 & + & - & - & + & + \\
\hline \multicolumn{12}{|c|}{ Utilization as sole nitrogen source: } \\
\hline L-Cysteine & + & + & + & + & + & - & + & + & + & + & - \\
\hline D-Glutamic acid & - & - & + & + & + & 50 & 50 & - & - & 88 & + \\
\hline Glycine & + & - & + & - & + & + & + & - & + & - & 86 \\
\hline D-Valine & - & - & - & + & + & - & - & - & - & - & - \\
\hline \multicolumn{12}{|l|}{ Antibiotic resistance $\left(\mu \mathrm{g} \mathrm{ml}^{-1}\right)$ : } \\
\hline Ampicillin (100) & + & + & + & + & + & - & + & + & + & 13 & + \\
\hline Chloramphenicol (100) & - & - & + & - & + & - & - & + & + & - & + \\
\hline Erythromycin (100) & - & - & - & + & + & - & + & - & - & 13 & + \\
\hline Kanamycin (5) & + & + & + & + & + & + & + & + & + & - & 14 \\
\hline Streptomycin (300) & + & - & + & - & - & + & 50 & - & + & - & 14 \\
\hline \multicolumn{12}{|l|}{ Chemical tolerance $(\%)$ : } \\
\hline Acridine hydrochloride $(0 \cdot 1)$ & - & - & + & - & + & - & - & + & + & - & - \\
\hline Methyl green $(0 \cdot 1)$ & + & + & - & + & + & + & + & + & + & - & - \\
\hline $\mathrm{NaCl}(3 \cdot 0)$ & - & + & + & + & 50 & + & 50 & - & + & 13 & - \\
\hline Growth at $\mathrm{pH} 5.0$ & - & - & + & + & + & - & - & - & - & - & - \\
\hline Urease activity & + & + & + & + & + & - & + & + & + & 25 & + \\
\hline Litmus milk acid coagulation & - & - & - & - & - & - & - & + & - & - & - \\
\hline Litmus milk alkali production & - & + & - & + & - & + & + & - & + & 75 & - \\
\hline Litmus milk peptonization & + & + & + & + & + & - & - & - & - & + & 29 \\
\hline \multicolumn{12}{|l|}{ Reduction of: } \\
\hline Litmus milk & + & - & + & - & + & - & - & - & - & 25 & + \\
\hline Methylene blue & + & - & + & 50 & + & - & + & - & + & - & 70 \\
\hline Nile blue & - & - & + & + & + & - & - & - & - & - & 14 \\
\hline
\end{tabular}

from two clones of each isolate were identical. Isolate CCBAU $71042^{\mathrm{T}}$ grouped with Rhizobium species, most similar to Rhizobium gallicum and Rhizobium mongolense (Fig. 3). The 16S rDNA sequence similarity between isolate CCBAU $71042^{\mathrm{T}}$ and $R$. mongolense USDA $1844^{\mathrm{T}}$, R. gallicum USDA $2918^{\mathrm{T}}$, Rhizobium tropici CIAT $899^{\mathrm{T}}$, $R$. tropici CFN 299, Rhizobium leguminosarum USDA $2370^{\mathrm{T}}$, Rhizobium etli CFN $42^{\mathrm{T}}$ 


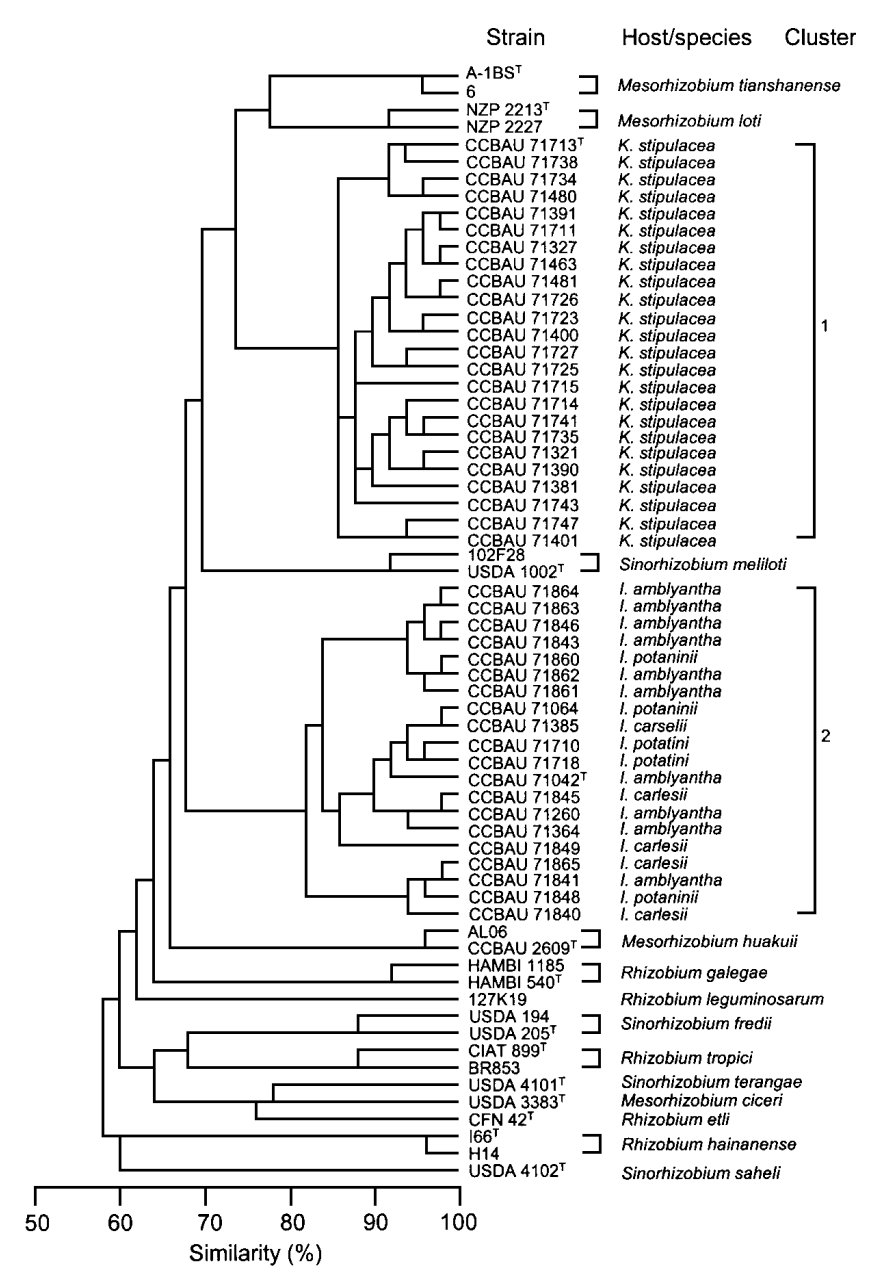

Fig. 2. Dendrogram showing the grouping results of SDS-PAGE patterns of whole-cell proteins extracted from the bacterial strains. The electrophoretic patterns were scanned by densitometer by using the $S_{j}$ coefficient and UPGMA (Sneath \& Sokal, 1973) as described by Tan et al. (1997). Clusters and defined species were separated at the similarity level of $82 \%$.

and Rhizobium hainanense $\mathrm{I}^{\mathrm{T}} 6^{\mathrm{T}}$ was respectively $97 \cdot 9$, $97 \cdot 7,95 \cdot 5,95 \cdot 4,96 \cdot 2,95 \cdot 8$ and $96 \cdot 3 \%$. Isolate CCBAU $71714^{\mathrm{T}}$ grouped within the Sinorhizobium phylogenetic branch, most related to Sinorhizobium xinjiangense and Sinorhizobium fredii. The $16 \mathrm{~S}$ rDNA sequence similarity between isolate CCBAU $71714^{\mathrm{T}}$ and $S$. xinjiangense CCBAU $110^{\mathrm{T}}$, S. fredii USDA $205^{\mathrm{T}}$, Sinorhizobium medicae USDA $1037^{\mathrm{T}}$, Sinorhizobium meliloti USDA $1002^{\mathrm{T}}$, Sinorhizobium saheli LMG $7837^{\mathrm{T}}$ and Sinorhizobium terangae LMG $7834^{\mathrm{T}}$ was respectively $98 \cdot 4,98 \cdot 5,97 \cdot 7,97 \cdot 8,98 \cdot 2$ and $96 \cdot 6 \%$. The phylogenetic relationships among the species of the genera Agrobacterium, Allorhizobium, Azorhizobium, Bradyrhizobium, Mesorhizobium, Rhizobium and Sinorhizobium in our reconstructed tree (Fig. 3) were similar to those in trees reported previously (Chen et al., 1997; de Lajudie et al., 1994, 1998a, b; Tan et al., 1997; Wang et al., 1998, 1999).

\section{DNA G + C contents and DNA-DNA hybridization}

These experiments were designed according to the results presented above. The results of DNA $\mathrm{G}+\mathrm{C}$ content estimation and DNA-DNA hybridization are shown in Table 3. Full details of the $\mathrm{G}+\mathrm{C}$ contents and DNA-DNA relatedness of the individual novel isolates are available as supplementary material in IJSEM Online (http://ijs.sgmjournals.org/). The DNA $\mathrm{G}+\mathrm{C}$ contents for the isolates from clusters 1 and 2 were respectively $59 \cdot 0-62 \cdot 0 \mathrm{~mol} \%$ and $59 \cdot 1-$ $61.8 \mathrm{~mol} \%$, which is in the range for Rhizobium (Jordan, 1984) and Sinorhizobium. The DNA-DNA relatedness among the isolates of each cluster was higher than $80 \%$ : within cluster 1 the range was $80 \cdot 6-94.9 \%$ (mean $88.2 \%$ ) and for cluster 2 the range was $83 \cdot 7-94 \cdot 0 \%$ (mean $89 \cdot 1 \%$ ). DNA-DNA relatedness between the representative isolate of cluster 1 (CCBAU $71042^{\mathrm{T}}$ ) and reference strains for Rhizobium species was 29.5-48.9\%. Low DNA relatedness $(5 \cdot 2-41 \cdot 7 \%)$ was obtained between isolate CCBAU $71714^{\mathrm{T}}$, representing cluster 2 , and reference strains for Sinorhizobium species (Table 3).

\section{Symbiotic performance}

The isolates of clusters 1 and 2 were able to nodulate both of the plants from which they were isolated. Isolate CCBAU 71042 ${ }^{\mathrm{T}}$, representing cluster 1, did not nodulate Astragalus sinicus, Medicago sativa, Galega orientalis, Lotus corniculatus, Vigna sinensis, Glycine max, Trifolium repens, Phaseolus vulgaris or Caragana korshinskii. Strain CCBAU $71714^{\mathrm{T}}$, representing cluster 2, nodulated Medicago sativa but not Astragalus sinicus, Galega orientalis, Lotus corniculatus, Vigna sinensis, Glycine max, Trifolium repens, Phaseolus vulgaris or Caragana korshinskii.

\section{DISCUSSION}

In this study, we characterized 21 nodule isolates from Indigofera and 27 nodule isolates from Kummerowia species from the north-western Loess Plateau of China by means of a polyphasic approach. Two main clusters, 1 and 2, were obtained among the isolates by numerical taxonomy based on phenotypic characterization (Fig. 1). The grouping results from SDS-PAGE of proteins (Fig. 2), analysis of DNA-DNA relatedness (Table 3) and PCR-based RFLP of 16S rRNA genes supported the results of numerical taxonomy and indicated that these two clusters were also two genomic groups or species. We concluded that cluster 1 was a member of Rhizobium and cluster 2 was a member of Sinorhizobium based upon the comparative analysis of $16 \mathrm{~S}$ rRNA gene sequences (Fig. 3). By analysis of DNADNA relatedness (Table 3), these two groups were different from related species in the genera Rhizobium and Sinorhizobium.

It is interesting that 20 isolates from Indigofera spp. and 24 isolates from $K$. stipulacea formed two groups, but they could share their host plants under laboratory 


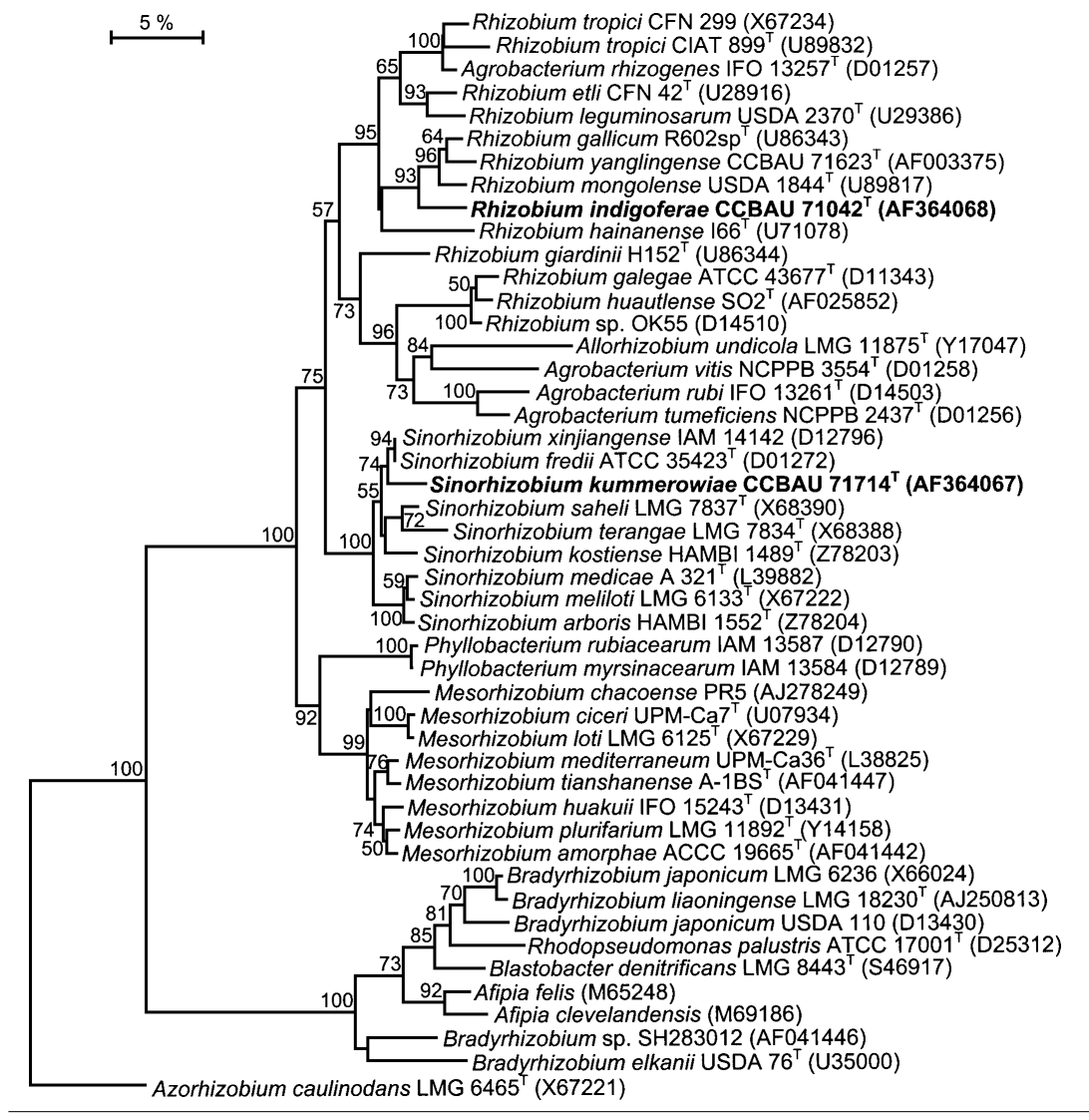

Fig. 3. Phylogram of $16 \mathrm{~S}$ rRNA gene sequences showing the phylogenetic relationships of the two novel groups obtained in this study and related species. Sequences were aligned using PILEUP. The phylogenetic tree was reconstructed and bootstrapped with 1000 subsamples using CLUSTAL W version 1.7 (Thompson et al., 1994). TreeView was used for visualizing the tree. Bootstrap values greater than $50 \%$ are indicated at the branching points. Bar, $5 \%$ base substitution. conditions. This observation may indicate that the host plant prefers some rhizobia for nodulation in nature. A similar situation was also observed among the rhizobia that nodulate Sesbania herbacea. Seedlings of $S$. herbacea can nodulate with other rhizobia within the genera Mesorhizobium, Rhizobium and Sinorhizobium when Rhizobium huautlense, the natural microsymbiont for this plant, is absent (Wang \& Martínez-Romero, 2000). Based on these results, we think that the original host(s) should be an important feature for description of the species and that they are more valuable for classification than cross-nodulation results under laboratory conditions.

Based on all the results, we propose two novel species, Rhizobium indigoferae sp. nov. for the cluster 1 isolates and Sinorhizobium kummerowiae sp. nov. for the cluster 2 isolates, according to the current criteria for description of new rhizobial species (Graham et al., 1991).

\section{Description of Rhizobium indigoferae sp. nov.}

Rhizobium indigoferae (in.di.go'fe.rae. N.L. gen. n. indigoferae of Indigofera, a genus of leguminous plants, referring to the host from which the bacterium was isolated).

Cells are aerobic, Gram-negative, non-spore-forming rods that are $0.4-0.7 \times 1.5-2.6 \mu \mathrm{m}$. Colonies are
2-3 mm in diameter after 2 days at $28^{\circ} \mathrm{C}$ and produce acid in YMA. Generation time is $2.2-3.8 \mathrm{~h}$ in PY broth. Can grow on YMA in the presence of $2.0 \%$ $\mathrm{NaCl}$. No growth at 4 or $40{ }^{\circ} \mathrm{C}$. Optimum $\mathrm{pH}$ is 6.5-7.5; no growth at $\mathrm{pH} 5 \cdot 0$. Uses dulcitol, $\mathrm{D}(+)-$ galactose, D-mannose, sodium citrate, salicin, sucrose, xylose and DL-asparagine, but not D-arabinose, calcium malonate or tartrate as sole carbon sources. Uses L-cysteine, but not glycine or D-valine as a sole nitrogen source. Sensitive to $100 \mu \mathrm{g}$ kanamycin and chloramphenicol ml $\mathrm{ml}^{-1}$ and $300 \mu \mathrm{g}$ streptomycin $\mathrm{ml}^{-1}$. No strain can grow in medium with acridine hydrochloride $(0 \cdot 1 \%)$ or methyl green $(0 \cdot 1 \%)$. Methylene blue reduction and nile-blue reduction are negative. Strains have been isolated from Indigofera spp. The DNA $\mathrm{G}+\mathrm{C}$ content is $59 \cdot 0-62 \cdot 0 \mathrm{~mol} \%\left(T_{\mathrm{m}}\right)$.

The type strain is strain CCBAU $71042^{\mathrm{T}}$ (=AS $\left.1.3054^{\mathrm{T}}\right)$. Its generation time is $2.6 \mathrm{~h}$ and its DNA $\mathrm{G}+\mathrm{C}$ content is $60 \cdot 1 \mathrm{~mol} \%\left(T_{\mathrm{m}}\right)$.

\section{Description of Sinorhizobium kummerowiae sp. nov.}

Sinorhizobium kummerowiae (kum.me.ro'wi.ae. N.L. gen. n. kummerowiae of Kummerowia, a genus of leguminous plants, referring to the host from which the bacterium was isolated).

Cells are aerobic, Gram-negative, non-spore-forming 
Table 3. DNA G + C contents and DNA-DNA relatedness among the novel isolates and defined species

DNA G $+\mathrm{C}$ contents were determined by the $T_{\mathrm{m}}$ method. ND, Not determined. Full details of the $\mathrm{G}+\mathrm{C}$ contents and DNA-DNA relatedness of the individual novel isolates are available as supplementary material in IJSEM Online (http://ijs.sgmjournals.org/).

\begin{tabular}{|c|c|c|c|}
\hline \multirow[t]{2}{*}{ Strain(s) or isolate(s) } & \multirow{2}{*}{$\begin{array}{c}\text { DNA G + C } \\
\text { content }(\mathrm{mol} \%)\end{array}$} & \multicolumn{2}{|c|}{ DNA-DNA hybridization with: } \\
\hline & & $\begin{array}{c}\text { CCBAU } 71042^{\mathrm{T}} \\
\quad(\text { cluster } 1)\end{array}$ & $\begin{array}{l}\text { CCBAU 71714 } \\
\quad \text { (cluster 2) }\end{array}$ \\
\hline \multicolumn{4}{|l|}{ Cluster 1 ( $R$. indigoferae sp. nov.) } \\
\hline CCBAU $71042^{\mathrm{T}}$ & $60 \cdot 1$ & 100 & ND \\
\hline 19 other isolates & $59 \cdot 0-62 \cdot 0$ & $80 \cdot 6-94 \cdot 9$ & ND \\
\hline \multicolumn{4}{|l|}{ Cluster 2 (S. kummerowiae sp. nov.) } \\
\hline CCBAU $71714^{\mathrm{T}}$ & $61 \cdot 6$ & ND & 100 \\
\hline 23 other isolates & $59 \cdot 1-61 \cdot 8$ & $\mathrm{ND}$ & $83 \cdot 7-96 \cdot 8$ \\
\hline R. leguminosarum USDA $2370^{\mathrm{T}}, 127 \mathrm{~K} 17$ & ND & $36 \cdot 4,30 \cdot 4$ & ND \\
\hline R. tropici type B CIAT $899^{\mathrm{T}}$ & ND & $38 \cdot 1$ & ND \\
\hline R. tropici type A CFN 299 & ND & $48 \cdot 9$ & ND \\
\hline R. etli CFN $42^{\mathrm{T}}$ & ND & $41 \cdot 7$ & ND \\
\hline R. hainanense $\mathrm{I}^{6} 6^{\mathrm{T}}, \mathrm{H} 14$ & ND & $32 \cdot 2,40 \cdot 3$ & ND \\
\hline R. gallicum USDA $2918^{\mathrm{T}}$ & ND & $30 \cdot 5$ & ND \\
\hline R. mongolense USDA $1844^{\mathrm{T}}$ & ND & $29 \cdot 5$ & ND \\
\hline R. yanglingense CCBAU $71623^{\mathrm{T}}$ & ND & $40 \cdot 1$ & ND \\
\hline S. arboris HAMBI $1552^{\mathrm{T}}$ & ND & ND & $24 \cdot 5$ \\
\hline S. kostiense HAMBI $1489^{\mathrm{T}}$ & ND & ND & $30 \cdot 2$ \\
\hline S. meliloti USDA $1002^{\mathrm{T}}, 102 \mathrm{~F} 28$ & ND & ND & $15 \cdot 6,25 \cdot 9$ \\
\hline S. medicae USDA $1037^{\mathrm{T}}$ & ND & ND & $5 \cdot 2$ \\
\hline S. fredii USDA $205^{\mathrm{T}}$, USDA 194 & ND & ND & $41 \cdot 7,39 \cdot 6$ \\
\hline S. xinjiangense CCBAU $110^{\mathrm{T}}$, CCBAU 108 & ND & ND & $16 \cdot 5,10 \cdot 2$ \\
\hline S. terangae LMG 7834 ${ }^{\mathrm{T}}$, LMG 6463 & ND & ND & $18 \cdot 7,20 \cdot 4$ \\
\hline S. saheli $\mathrm{LMG} 7837^{\mathrm{T}}$ & ND & ND & $37 \cdot 3$ \\
\hline
\end{tabular}

rods that are $0.3-0.6 \times 1.8-3.0 \mu \mathrm{m}$. Colonies are $2-3 \mathrm{~mm}$ in diameter after $1-2$ days at $28^{\circ} \mathrm{C}$ and produce acid in YMA. Generation time is $2 \cdot 0-3 \cdot 0 \mathrm{~h}$ in PY broth. Sensitive to $3.0 \%(\mathrm{w} / \mathrm{v}) \mathrm{NaCl}$ in YMA. No growth at 4 or $40{ }^{\circ} \mathrm{C}$. Optimum $\mathrm{pH}$ is $6 \cdot 5-7 \cdot 5$; no growth at $\mathrm{pH} 5 \cdot 0$. Uses dulcitol, DL-asparagine and glycine, but not D-amygdalin, D-arabinose, calcium malonate, lactose, tartrate, D-ribose, sodium D-gluconate, trehalose, D-mannose or sodium citrate as sole carbon sources. Uses D-glutamic acid but not Lcysteine or D-valine as a sole nitrogen source. Not sensitive to $100 \mu \mathrm{g}$ ampicillin, chloramphenicol or erythromycin $\mathrm{ml}^{-1}$. No strain can grow in medium with acridine hydrochloride $(0 \cdot 1 \%)$ or methyl green $(0 \cdot 1 \%)$. No growth in Luria-Bertani broth. Strains have been isolated from Kummerowia stipulacea. The DNA $\mathrm{G}+\mathrm{C}$ content is $59 \cdot 1-61 \cdot 8 \mathrm{~mol} \%\left(T_{\mathrm{m}}\right)$.

The type strain is strain CCBAU $71714^{\mathrm{T}}$ (=AS $\left.1.3046^{\mathrm{T}}\right)$. Its generation time is $2 \cdot 2 \mathrm{~h}$ and its DNA $\mathrm{G}+\mathrm{C}$ content is $61.6 \mathrm{~mol} \%\left(T_{\mathrm{m}}\right)$.

\section{ACKNOWLEDGEMENTS}

This research was part of project no. 39130010 supported by the National Science Foundation of China.

\section{REFERENCES}

Allen, O. N. \& Allen, E. K. (1981). The Leguminosae: a Source Book of Characteristics, Uses, and Nodulation. Madison, WI: University of Wisconsin Press.

Amarger, N., Macheret, V. \& Laguerre, G. (1997). Rhizobium gallicum sp. nov. and Rhizobium giardinii sp. nov., from Phaseolus vulgaris nodules. Int J Syst Bacteriol 47, 996-1006.

Casida, L. E., Jr (1982). Ensifer adhaerens gen. nov., sp. nov.: a bacterial predator of bacteria in soil. Int J Syst Bacteriol 32, 339-345. Chen, W. X., Yan, G. H. \& Li, J. L. (1988). Numerical taxonomic study of fast-growing soybean rhizobia and proposal that Rhizobium fredii be assigned to Sinorhizobium gen. nov. Int J Syst Bacteriol 38, 392-397.

Chen, W. X., Li, G. S., Qi, Y. L., Wang, E. T., Yuan, H. L. \& Li, J. L. (1991). Rhizobium huakuii sp. nov. isolated from the root nodules of Astragalus sinicus. Int J Syst Bacteriol 41, 275-280.

Chen, W.-X., Tan, Z.-Y., Gao, J.-L., Li, Y. \& Wang, E.-T. (1997). Rhizobium hainanense sp. nov., isolated from tropical legumes. Int $J$ Syst Bacteriol 47, 870-873.

Chen, W.-M., Laevens, S., Lee, T.-M., Coenye, T., De Vos, P., Mergaey, M. \& Vandamme, P. (2001). Ralstonia taiwanensis sp. nov., isolated from root nodules of Mimosa species and sputum of a cystic fibrosis patient. Int J Syst Evol Microbiol 51, 1729-1735.

de Lajudie, P., Willems, A., Pot, B. \& 7 other authors (1994). Polyphasic taxonomy of rhizobia: emendation of the genus Sinorhizobium and description of Sinorhizobium meliloti comb. nov., Sinorhizobium saheli sp. nov., and Sinorhizobium teranga sp. nov. Int J Syst Bacteriol 44, 715-733.

de Lajudie, P., Willems, A., Nick, G. \& 9 other authors (1998a). 
Characterization of tropical tree rhizobia and description of Mesorhizobium plurifarium sp. nov. Int J Syst Bacteriol 48, 369-382.

de Lajudie, P., Laurent-Fulele, E., Willems, A., Torck, U., Coopman, R., Collins, M. D., Kersters, K., Dreyfus, B. \& Gillis, M. (1998b). Allorhizobium undicola gen. nov., sp. nov., nitrogen-fixing bacteria that efficiently nodulate Neptunia natans in Senegal. Int J Syst Bacteriol 48, $1277-1290$

De Ley, J. (1970). Reexamination of the association between melting point, buoyant density, and chemical base composition of deoxyribonucleic acid. $J$ Bacteriol 101, 738-754.

De Ley, J., Cattoir, H. \& Reynaerts, A. (1970). The quantitative measurement of DNA hybridization from renaturation rates. Eur $J$ Biochem 12, 133-142.

Dreyfus, B., Garcia, J. L. \& Gillis, M. (1988). Characterization of Azorhizobium caulinodans gen. nov., sp. nov., a stem-nodulating nitrogen-fixing bacterium isolated from Sesbania rostrata. Int J Syst Bacteriol 38, 89-98.

Gao, J. L., Sun, J. G., Li, Y., Wang, E. T. \& Chen, W. X. (1994). Numerical taxonomy and DNA relatedness of tropical rhizobia isolated from Hainan Province, China. Int J Syst Bacteriol 44, 151-158.

Genetics Computer Group (1995). Program Manual for the Wisconsin Package, Version 8. Madison, WI: Genetics Computer Group.

Graham, P. H., Sadowsky, M. J., Keyser, H. H. \& 8 other authors (1991). Proposed minimal standards for the description of new genera and species of root- and stem-nodulating bacteria. Int $J$ Syst Bacteriol 41, 582-587.

Jarvis, B. D. W., Pankhurst, C. E. \& Patel, J. J. (1982). Rhizobium loti, a new species of legume root nodule bacteria. Int J Syst Bacteriol 32, 378-380.

Jarvis, B. D. W., van Berkum, P., Chen, W. X., Nour, S. M., Fernandez, M. P., Cleyet-Marel, J.-C. \& Gillis, M. (1997). Transfer of Rhizobium loti, Rhizobium huakuii, Rhizobium ciceri, Rhizobium mediterraneum, and Rhizobium tianshanense to Mesorhizobium gen. nov. Int $J$ Syst Bacteriol 47, 895-898.

Jordan, D. C. (1982). Transfer of Rhizobium japonicum Buchanan 1980 to Bradyrhizobium gen. nov., a genus of slow-growing, root nodule bacteria from leguminous plants. Int J Syst Bacteriol 32, 136-139.

Jordan, D. C. (1984). Family III. Rhizobiaceae Conn 1938, 321 ${ }^{\mathrm{AL}}$. In Bergey's Manual of Systematic Bacteriology, vol. 1, pp. 234-235. Edited by N. R. Krieg \& J. G. Holt. Baltimore: Williams \& Wilkins.

Kuykendall, L. D., Saxena, B., Devine, T. E. \& Udell, S. E. (1992). Genetic diversity in Bradyrhizobium japonicum Jordan 1982 and a proposal for Bradyrhizobium elkanii sp. nov. Can J Microbiol 38, 501-505.

Lindström, K. (1989). Rhizobium galegae, a new species of legume root nodule bacteria. Int J Syst Bacteriol 39, 365-367.

Marmur, J. (1961). A procedure for the isolation of DNA from microorganisms. J Mol Biol 3, 208-218.

Martínez-Romero, E., Segovia, L., Mercante, F. M., Franco, A. A., Graham, P. \& Pardo, M. A. (1991). Rhizobium tropici, a novel species nodulating Phaseolus vulgaris L. beans and Leucaena sp. trees. Int J Syst Bacteriol 41, 417-426.

Moulin, L., Munive, A., Dreyfus, B. \& Boivin-Masson, C. (2001). Nodulation of legumes by members of the $\beta$-subclass of Proteobacteria. Nature 411, 948-950.

Nour, S. M., Fernandez, M. P., Normand, P. \& Cleyet-Marel, J.-C. (1994). Rhizobium ciceri sp. nov., consisting of strains that nodulate chickpeas (Cicer arietinum L.). Int J Syst Bacteriol 44, 511-522.

Nour, S. M., Cleyet-Marel, J.-C., Normand, P. \& Fernandez, M. P. (1995). Genomic heterogeneity of strains nodulating chickpeas (Cicer arietinum L.) and description of Rhizobium mediterraneum sp. nov. Int J Syst Bacteriol 45, 640-648.

Page, R. D. M. (1996). TreeView: an application to display phylogenetic trees on personal computers. Comput Appl Biosci 12, 357-358.
Rome, S., Fernandez, M. P., Brunel, B., Normand, P. \& CleyetMarel, J.-C. (1996). Sinorhizobium medicae sp. nov., isolated from annual Medicago spp. Int J Syst Bacteriol 46, 972-980.

Sambrook, J., Fritsch, E. F. \& Maniatis, T. (1989). Molecular Cloning: a Laboratory Manual, 2nd edn. Cold Spring Harbor, NY: Cold Spring Harbor Laboratory.

Scholla, M. H. \& Elkan, G. H. (1984). Rhizobium fredii sp. nov., a fastgrowing species that effectively nodulates soybeans. Int $J$ Syst Bacteriol 34, $484-486$.

Segovia, L., Young, J. P. W. \& Martínez-Romero, E. (1993). Reclassification of American Rhizobium leguminosarum biovar phaseoli type I strains as Rhizobium etli sp. nov. Int J Syst Bacteriol 43, 374-377.

Sneath, P. H. A. \& Sokal, R. B. (1973). Numerical Taxonomy. The Principles and Practice of Numerical Classification. San Francisco: W. H. Freeman and Co.

Sy, A., Giraud, E., Jourand, P. \& 8 other authors (2001). Methylotrophic Methylobacterium bacteria nodulate and fix nitrogen in symbiosis with legumes. $J$ Bacteriol 183, 214-220.

Tan, Z.-Y., Xu, X.-D., Wang, E.-T., Gao, J.-L., Martinez-Romero, E. \& Chen, W.-X. (1997). Phylogenetic and genetic relationships of Mesorhizobium tianshanense and related rhizobia. Int J Syst Bacteriol 47, 874-879.

Tan, Z. Y., Wang, E. T., Peng, G. X., Zhu, M. E., Martínez-Romero, E. \& Chen, W. X. (1999). Characterization of bacteria isolated from wild legumes in the north-western regions of China. Int J Syst Bacteriol 49, 1457-1469.

Thompson, J. D., Higgins, D. G. \& Gibson, T. J. (1994). ClustaL W: improving the sensitivity of progressive multiple sequence alignment through sequence weighting, position-specific gap penalties and weight matrix choice. Nucleic Acids Res 22, 4673-4680.

Tiesman, J. \& Rizzino, A. (1991). A rapid and reliable method for the purification of high-quality plasmid DNA for double-stranded sequencing. Biotechniques 10, 319, 326-328.

van Berkum, P., Beyene, D., Bao, G., Campbell, T. A. \& Eardly, B. D. (1998). Rhizobium mongolense sp. nov. is one of three rhizobial genotypes identified which nodulate and form nitrogen-fixing symbioses with Medicago ruthenica [(L.) Ledebour]. Int J Syst Bacteriol 48, 13-22. Vincent, J. M. (1970). A Manual for the Practical Study of Root Nodule Bacteria. Oxford: Blackwell Scientific.

Wang, E. T. \& Martínez-Romero, E. (2000). Sesbania herbaceaRhizobium huautlense nodulation in flooded soils and comparative characterization of $S$. herbacea-nodulating rhizobia in different environments. Microb Ecol 40, 25-32.

Wang, E. T., van Berkum, P., Beyene, D., Sui, X. H., Dorado, O., Chen, W. X. \& Martínez-Romero, E. (1998). Rhizobium huautlense sp. nov., a symbiont of Sesbania herbacea that has a close phylogenetic relationship with Rhizobium galegae. Int J Syst Bacteriol 48, 687-699.

Wang, E. T., van Berkum, P., Sui, X. H., Beyene, D., Chen, W. X. \& Martínez-Romero, E. (1999). Diversity of rhizobia associated with Amorpha fruticosa isolated from Chinese soils and description of Mesorhizobium amorphae sp. nov. Int J Syst Bacteriol 49, 51-65.

Wieslander, L. (1979). A simple method to recover intact high molecular weight RNA and DNA after electrophoretic separation in low gelling temperature agarose gels. Anal Biochem 98, 305-309.

Willems, A. \& Collins, M. D. (1993). Phylogenetic analysis of rhizobia and agrobacteria based on 16S rRNA gene sequences. Int $J$ Syst Bacteriol 43, 305-313.

Xu, L. M., Ge, C., Cui, Z., Li, J. \& Fan, H. (1995). Bradyrhizobium liaoningense sp. nov., isolated from the root nodules of soybeans. Int $J$ Syst Bacteriol 45, 706-711.

Yanagi, M. \& Yamasato, K. (1993). Phylogenetic analysis of the family Rhizobiaceae and related bacteria by sequencing of 16S rRNA gene using PCR and DNA sequencer. FEMS Microbiol Lett 107, 115-120.

Yelton, M. M., Yang, S. S., Edie, S. A. \& Lim, S. T. (1983). Characterization of an effective salt-tolerant, fast-growing strain of Rhizobium japonicum. J Gen Microbiol 129, 1537-1547. 